\title{
Evaluation of Bisphenol A, Physicochemical Properties and Microbial Characterization of Borehole Water Stored in Plastic Containers
}

\author{
*11ADEGHE, OM; EMEJULU, MJ
}

\author{
${ }^{1}$ Department of Environmental Management and Toxicology, Faculty of Life Sciences, University of Benin, Nigeria \\ ${ }^{2}$ Departments of Environmental Management and Toxicology, Faculty of Life Sciences, University of Benin, Nigeria \\ Corresponding Author: maurice.adeghe@uniben.edu
}

\begin{abstract}
The aim of this study was to evaluate the bisphenol A (BPA), physicochemical properties and microbial characterization of borehole water stored in plastic containers. Three brands of plastic containers filled with borehole water were collected from homes in Ugbowo, Benin city. Physicochemical parameters were determined using standard methods. Total bacterial and coliform counts were determined using the pour plate technique. Conductivity, TDS, Chloride, Sulphate and Nitrate were within the recommended standards while turbidity and total iron were above recommended standards. The isolates identified include: Klebsiella sp, Bacillus sp, E. coli, Pseudomonas aeruginosa, Aspergillus flavus, Saccharomyces sp and Aspergillus niger. The total bacterial count in the water samples ranged from $1.4 \times 10^{3} \mathrm{cfu} / \mathrm{ml}$ to $1.8 \times 10^{3} \mathrm{cfu} / \mathrm{ml}$ at week four while fungal counts was $1.3 \times 10^{2} \mathrm{cfu} / \mathrm{ml}$ to $1.6 \times 10^{2} \mathrm{cfu} / \mathrm{ml}$. Bisphenol A (BPA) was discovered to leach at detectable levels from the plastic containers as storage increased. The result of the Bisphenol A analysis revealed that BPA congeners ranged from $0.023 \mathrm{mg} / 1$ within days of collection to $0.251 \mathrm{ml} / 1$ at the fourth week of storage. This study has shown that storage of borehole water in plastic containers for prolonged period affects the bacteriological and chemical properties of the water; hence storage of borehole water in plastic for prolonged periods should be discouraged and discontinued. @JASEM
\end{abstract}

http://dx.doi.org/10.4314/jasem.v20i4.28

Keywords: Plastic contaminant, physicochemical properties, Borehole water, Bisphenol A, Microbial characterization, Storage period

Bisphenol A (BPA) is predominantly an intermediate to the production of other products. Its main use include binding, plasticizing and hardening functions in plastic products, paints/lacquers, binding materials and filling-in materials (Makinwa and Uadia 2015). However, exposure to BPA occurs primarily via hydrolysis of polycarbonate plastics and epoxy resins resulting in low concentration of free BPA in food and liquids thus making dietary consumption the major mode of human exposure (Wilson et al., 2007). Water is a transparent, colourless, odourless and tasteless liquid that makes up the sea, lakes, rivers, rainfall as well as the liquid that makes up living organisms (Michael, 2000). Water is a compound of two elements; hydrogen and oxygen atoms with a chemical formula $\mathrm{H}_{2} \mathrm{O}$ and it is known to make up about 70 percent of the earth surface (Osei, 2005). Rivers, streams, wells and more recently boreholes, serve as the main source of drinking water and domestic use in developing countries like Nigeria, where most of the people reside in rural areas (Ibe and Okplenya, 2005). According to the World Health Organisation guidelines for drinking water underground water supplies are usually considered safe provided they are properly located, constructed and operated to WHO regulatory standards (WHO,1971).Boreholes with hand pumps are commonly used by poor rural communities and this amounts to approximately 250,000 hand pumps in Africa. Studies have shown that water may become contaminated at any point between collection, storage and usage (Tambekar et al., 2006). Also, storing water in plastic containers and handling procedures of water at homes, hotels or restaurants causes' water quality deterioration to such extent that it becomes potential risk of infection to consumers (Jagals et al., 1999).

Microorganisms associated with contaminated water include Salmonella sp, Escherichia coli and Vibro cholera (Birmingham et al., 1997). Water borne diseases often arises when pathogenic microorganisms associated with contaminated water is consumed. Boreholes and wells are polluted industrially, domestically and agriculturally. Industrial pollution may involve seepages of used water containing chemicals such as metals and radioactive compounds while domestic pollution may involve seepage from broken septic tanks, pit latrines and privies. Runoff water after rainfall carrying pesticides, fertilizers, herbicides and faecal matter may contribute to agricultural pollution. However the pollution sources, the quality of packaging plastic bottle cannot guarantee safety from contamination. In the natural environment there are compound that have the potential to disturb equilibrium in living organisms and are mistakenly recognised by oestrogen receptors, treated the same as those naturally present in the organism. Substances of this type are known as Endocrine Disrupting chemicals. 
Bisphenol A is one of the highest volume chemicals produced worldwide with more than 6million pounds produced each year (Burridge, 2003). It serves as a base line in the manufacturing of plastics and a major compound in the production of epoxy resins, printers ink, powdered paints, dental sealants and composites (Vandenberg et al ., 2009; Markey et al., 2003). Bisphenol A can be released and leached into water from packaging materials. Hence, through consumption due to it use in packaging and storage containers, consumers are directly or chronically exposed to BPA (Brotons et al., 1995). Several health cases have been attributed to bisphenol $\mathrm{A}$ and studies have been carried out on the chemical component at different scales. Some researchers have focused on the detection and measurement of bisphenol A while others on the effects on humans and laboratory animals(Chang et al.,2009). For example a study in the United States has evaluated the presence of BPA in packaged water (Jin et al., 2004). In Iran, Raskari et al. (2011) and Jafari et al. (2006) investigated the presence of BPA in canned foods, surface water an d waste water. Makinwa and Uadia (2015) carried out a survey on the levels of BPA in effluents, soil leachates, food samples, drinking water and consumer products in South Western Nigeria. However it seems that no study has been done on the measurement of BPA in borehole water filled into plastic containers in Nigeria. This study evaluated the bisphenol a (BPA), physicochemical properties as well as the microbial characterization of borehole water stored in plastic containers.

\section{MATERIALS AND METHOD}

A total of three different brands of plastic containers filled with borehole water samples were collected from Ugbowo in Benin City. The samples were stored at room temperature for four weeks, thus mimicking typical conditions in retail outlets, supermarkets and in homes. Sub-samples were drawn from the stock samples on weekly basis and within days of being purchased for microbiological and physicochemical analysis, using WHO analytical methods (WHO, 2011). Water samples for analysis of dissolved oxygen (DO) and biochemical oxygen demand (BOD) were collected in pre-sterilized brown bottle and fixed by adding $1.2 \mathrm{ml}$ of Winkler solution.

Microbiological Analysis of Water Samples: Total viable bacterial and fungal counts were determined by pour plate technique using standard methods (APHA, 1998). Nutrient agar medium was used for the enumeration of viable aerobic bacteria while Sabouraud dextrose agar was used for fungal count.
MacConkey agar was used for coliform count while eosin methylene blue medium was used for faecal coliform and E.coli counts. The different brands of borehole water samples were serially diluted upto $10^{-}$ 3 dilution/ then $0.1 \mathrm{ml}$ of the appropriate dilutions were plated in Nutrient agar, Sabourand agar, MacConkey and Eosin methylene blue media. Nutrient and MacConkey agar plates were incubated at $37^{\circ} \mathrm{C}$ for $24 \mathrm{hr}$, while Sabouraud and eosin methylene blue agar plates were incubated at room temperature for $72 \mathrm{hr}$ and at $44.5^{\circ} \mathrm{C}$ respectively. After incubation, the number of discrete colonies were counted and recorded in colony forming unit per millilitre (cfu/ml).

The isolates were sub-cultured to obtain pure cultures. The pure cultures so obtained were transferred to agar slants by streaking and further biochemical tests were carried-out to identify the isolates. Faecal coliform count that was determined using pour plate technique was recorded by the organism's ability to appear as greenish metallic sheen. This was taken as positive for E.coli. However further confirmatory test was carried out by the ability of the organisms to ferment lactose at $44.4^{0} \mathrm{C}$.

Identification of Microbial Isolates: By streaking on their respective media plates, aseptically purified representatives of discrete colonies were obtained. They were further stored in agar slants for further characterization. All the bacterial and fungal isolates were initially examined microscopically for morphological characterization followed by appropriate biochemical test for bacterial isolates (Gram staining, indole, catalase, motility, citrate utilization, urea production, oxidase, congulase and oxidative/fermentative utilization of lactose and glucose). The identification of bacterial isolates was done in accordance with criteria of Bergeys manual of Determining Bacteria (Holt et al., 1994)

Fungi isolates were identified microscopically using lacto phenol cotton blue test. The identification was achieved by placing a drop of the stain on clean slide with the aid of a wire loop, where a small portion of the mycelium from the fungal cultures was removed and placed in a drop of lactophenol. The mycelium was spread on the slide with aid of wire loop. A cover slip was gently applied with little pressure to eliminate air bubbles. The slide was then mounted and observed with objective lens and identification done in accordance with Barneth and Hunter (1982) criteria. 
Physicochemical Analysis of borehole Water Samples: Physicochemical parameters determined included: $\mathrm{pH}$, temperature, conductivity, total dissolved solid (TDS), total suspended solid (TSS), turbidity, alkalinity, total hardness, total iron, chloride, sulphate, phosphate, nitrate and biochemical oxygen demand (BOD). In carrying out this analysis various sub-samples drawn from stock samples (stored) were taken to the laboratory in ice-packed coolers. Those that could not be analyzed the same day were stored in a refrigerator at a temperature of $4^{0} \mathrm{C}$. All the physicochemical analysis was carriedout using standard method (APHA, 1998). Data collected were subjected to statistical analysis.

Sample Treatment and Analysis for Bisphenol a $(B P A)$ : Bisphenol A was extracted from water samples using the modified procedure from Dean and Xion (2000). Fifty millilitre $(50 \mathrm{ml})$ of water sample was measured into a separating funnel in which 100 $\mathrm{ml}$ of dichloromethane (DCM) and shaked for 30min. The separating funnel was clamp and the mixture was allowed to separate-out. After separation, the DCM portion was collected. The process was repeated three times for complete extraction. Blanks were prepared following the same procedures without sample using deionized water. The standard sample used for quality control was prepared by adding the standard solution (Bisphenol A) to DCM. The extracts were separated, and activated copper was added to the combined extracts for desulphurization. After subsequent filtration over anhydrous sodium sulphate, the solution was concentrated to $1.0 \mathrm{ml}$ using a rotary evaporator; an internal standard mixture (Vinyl chloride) solution was run with the extract for quality control check using Hewlett Packard HP 5890 series II gas chromatograph with mass selective detection (GC-MS).

GC-MS Instrumentation and Conditions: Hewlett Packard HP 5890 series II Gas chromatograph equipped with an Agilent 7683B injector (Agilent Technologies Santa Clara, CA, USA), A 30m, $0.25 \mathrm{~mm}$ id. HP-5MS capillary column (Hewlett Packard, Palo Alto, CA, USA) coated with 5\% phenyl-methylsiloxane (film thickness $0.25 \mu \mathrm{m}$ ) and an Agilent 5975 mass selective detector (MSD) was used to separate and quantify the BPA compounds. The samples were injected in the split less mode at an injection temperature of $300^{\circ} \mathrm{C}$. The transfer line and ion source temperatures were $280^{\circ} \mathrm{C}$ and $200^{\circ} \mathrm{C}$. The column temperature was initially held at $40^{\circ} \mathrm{C}$ for $1 \mathrm{~min}$, raised to $120^{\circ} \mathrm{C}$ at the rate of $25^{\circ} \mathrm{C} / \mathrm{min}$, then to $160^{\circ} \mathrm{c}$ at the rate of $10^{\circ} \mathrm{C} / \mathrm{min}$ and finally to $300^{\circ} \mathrm{C}$ at $5^{\circ} \mathrm{C} / \mathrm{min}$, held at final temperature for $15 \mathrm{~min}$. Detector temperature was kept at $280^{\circ} \mathrm{C}$. Helium was used as a carries gas at a constant flow rate of $\mathrm{ml} / \mathrm{min}$. Mass spectrometry was acquired using the electron ionization (EI) and selective ion monitoring (SIM) mode.

\section{RESULTS AND DISSCUSION}

Table 1: Concentration of Bisphenol A in Plastic Bottles filled with Borehole water Samples

\begin{tabular}{lllll}
\hline Parameter & Week 0 & Week 1 & Week 4 & Standard \\
\hline Methylene chloride & 0.015 & 0.031 & 0.065 & 1.0 \\
Hexane & $<0.001$ & $<0.001$ & $<0.001$ & 1.0 \\
Chloroform & $<0.001$ & 0.001 & 0.001 & 1.0 \\
Toluene & $<0.001$ & $<0.001$ & $<0.001$ & 1.0 \\
Benzene & $<0.001$ & $<0.001$ & $<0.001$ & 1.0 \\
Vinyl chloride & 0.008 & 0.067 & 0.164 & 5.0 \\
Tetrachloroethylene & $<0.001$ & 0.015 & 0.021 & 1.0 \\
Chlorobenzene & $<0.001$ & $<0.001$ & $<0.001$ & 1.0 \\
Dichlorobenzene & $<0.001$ & $<0.001$ & $<0.001$ & 1.0 \\
Total (mg/l) & $\mathbf{0 . 0 2 3}$ & $\mathbf{0 . 1 1 4}$ & $\mathbf{0 . 2 5 1}$ & \\
\hline
\end{tabular}

As shown in table 1 , the borehole water samples refilled into plastic containers contained high levels of BPA congeners ranging from $0.023 \mathrm{mg} / \mathrm{l}$ to $0.251 \mathrm{mg} / \mathrm{l}$ at week 4 . This result is in tandem with Atuanya et al. (2016) who investigated the bioavailability of plastic contaminants and their effects on plastic bottled and sachet drinking water supplies. A progressive increase in the concentration of BPA congeners as storage increased was recorded. Although there was a significant higher level, this result has shown that there was a gradual release of BPA congeners that increased with storage period. 
Table 2: Physicochemical properties of borehole water in plastic containers

\begin{tabular}{lllll}
\hline Parameters & Week 0 & Week 1 & Week 4 & $\begin{array}{l}\text { WHO (2011) } \\
\text { water standards }\end{array}$ \\
\hline pH & 6.6 & 5,6 & 5.6 & $6.5-\mathrm{S} .5$ \\
Temperature $\left({ }^{\circ} \mathrm{C}\right)$ & 32.9 & 32.2 & 32.5 & \\
Conductivity $(\mathrm{us} / \mathrm{cm})$ & 40.6 & 29.0 & 29.5 & 900 \\
TDS $(\mathrm{mg} / \mathrm{L})$ & 15.5 & 7.8 & 9.5 & 1000 \\
TSS $(\mathrm{mg} / \mathrm{L})$ & 7.5 & 6.0 & 3.5 & \\
Turbidity & 5.30 & 5.80 & 5.50 & 5 \\
Alkalinity $(\mathrm{mg} / \mathrm{L})$ & 8.0 & 12.0 & 8.0 & \\
Total hardness(mg/L) & 42.90 & 44.60 & 43.10 & \\
Total iron(mg/L) & 1.031 & 1.051 & 1.001 & 0.30 \\
Chloride $(\mathrm{mg} / \mathrm{L})$ & 10.6 & 11.5 & 9.7 & 250 \\
Sulphate $(\mathrm{mg} / \mathrm{L})$ & $8 \wedge 22$ & 8.23 & 8.21 & 400 \\
Nitrate $(\mathrm{mg} / \mathrm{L})$ & 0.22 & 0.24 & 0.22 & 50 \\
Phosphate(mg/L) & 102.0 & 115.2 & 96.8 & 6.5 \\
BOD(mg/L) & 26.4 & 36.0 & 33.6 & \\
\hline
\end{tabular}

The result of the physicochemical analysis of the borehole water showed an increase in the $\mathrm{pH}$ from 6.6 in week 0 to 5.6 in week 4 as shown in table 2 . Akinde et al. (2011) and Agbaje et al. (2012) obtained similar results for stored sachet and borehole water samples. A low $\mathrm{pH}$ encourages corrosion of pipes while a $\mathrm{pH}$ above 7 requires more chlorine and contact time for proper disinfection. Turbidity values ranged from 5.30 in week 0 to 5.80 NTU in week4. These values were above the maximum acceptable limit of 5NTU recommended by WHO. This high level of turbidity in plastic bottle filled with borehole water is a source of concern because the particles forming the turbidity could habour and shield pathogenic microorganisms and hence escape the action of disinfection (EPA, 2001). The total iron also increase from $1.031 \mathrm{mg} / \mathrm{l}$ to $1.051 \mathrm{mg} / 1$ in week 4 and exceeded the WHO recommended standard. This element is present in ground water in the soluble ferrous form $\left(\mathrm{Fe}^{2+}\right)$. It is easily oxidized to the insoluble ferric $\left(\mathrm{Fe}^{3+}\right)$ upon exposure to air

Table 3: Microbial Counts of Borehole Water

\begin{tabular}{lccc}
\hline \multicolumn{3}{c}{ Plastic bottle filled with borehole water } \\
\hline & Week 0 & Week 1 & Week 4 \\
Total viable bacteria count & $1.4 \times 10^{3}$ & $1.6 \times 10^{3}$ & $1.8 \times 10^{3}$ \\
Total Coliform count & $4.7 \times 10^{2}$ & $4.4 \times 10^{2}$ & $4.9 \times 10^{2}$ \\
E. coli count & $6.0 \times 10^{1}$ & $5.0 \times 10^{1}$ & $7.0 \times 10^{1}$ \\
Fungal count & $1.3 \times 10^{2}$ & $1.0 \times 10^{2}$ & $1.6 \times 10^{2}$ \\
\hline
\end{tabular}

The result of this study has revealed the effect of prolonged storage of borehole water samples stored at room temperature on the total heterotrophic bacterial count. Increase in storage of the samples led to a gradual increase in the total heterotrophic bacteria count as shown in table 3 . This result is in line with (Atuanya et al., 2014) who revealed the effect of storage on the physicochemical and bacteriological qualities of potable water in Benin City. Total coliform count recorded ranged from $4.7 \times$ $10^{2} \mathrm{cfu} / \mathrm{ml}$ in week 0 to $4.9 \times 10^{2} \mathrm{cfu} / \mathrm{ml}$ in week 4 . This result is also in accordance with Rogbesan et al. (2002) who reported the presence of total coliform count above the range recommended by WHO. The observation from this result reveals that high heterotrophic bacteria count also reflected in total coliform count. E.coli and fungal counts recorded ranged from $6.0 \times 10^{1} \mathrm{cfu} / \mathrm{ml}$ to $7.0 \times 10^{1} \mathrm{cfu} / \mathrm{ml}$ and $1.3 \times 10^{2} \mathrm{cfu} / \mathrm{ml}$ to $1.6 \times 10^{2} \mathrm{cfu} / \mathrm{ml}$ respectively. The presence of high heterotrophic bacteria count, total coliform count, E.coli and fungal count could be as a result of the proximity of the borehole to a pit latrine at a distance less than 30meters that is recommended by WHO or as a result of the nature of the pipes used for the distribution of the water. They may be rusty, thus allowing seepage of microbial contamination into the borehole. The bacterial and fungal isolate identified in this study showed that the water is not wholesome, therefore not fit for consumption without additional treatment.

Conclusion: The result of this study has shown that the levels of bacterial population in borehole water stored at room temperature increased to maximum levels at the fourth week of water storage. It also showed that the bioavailability of bisphenol A components in borehole water, appeared to start manifesting at the fourth week of water storage. Storage temperature for long period plays a major role, creating impact on the acceptability of other organic constituents and enhancing the growth of microorganisms. Finally it is obvious from this study that BPA leaching from plastic containers into water can be affected by storage temperature and time, 
hence proper awareness should be created on the emergence of such an endocrine disrupting chemical.

\section{REFERENCES}

Agbaje, L.; Lateef, K; Semawon, OA (2012) Quality of assessment of some ground water samples in Ogbomoso metropolis, Southern Nigeria.

Journal of Environment And Earth Science 2(6): $39-48$

Akinde, SB; Michael, IN; Adindu, SO (2011) Storage effect on the quality of sachet water produced within Port Harcourt metropolis, Nigeria. Jordan Journal of Biological Sciences 4:157-164

APHA, (1998) Standards methods for the examination of water and waste water $.18^{\text {th }}$ edn. American public health association, Washington DC

Atuanya, EI; Seidu, RI; Orjiakor, PI (2014). Effects of storage/biofilm formation on physic chemical and bacteriological qualities of potable water supply in Benin City. Nigerian Society Of Experimental Biology Journal 14 (3): 59-66

Barnett, HL; Hunter, BB (1982) Illustrated general of imperfect gungi. $4^{\text {th }}$ edn. Burgress publishers. Coy.USA

Birmigham, ME; Lea, LA; Ndayiminje, N; Nkurikiye, S; Hersh, BS; Wells, JG; Ijeming, MS.(1997) Epidemic cholera in Burundi, patterns of transmission in the Gadat riff valley lake region. Lancet 349:981-983

Brotons, JA; Olea-serrano, MF; Villalobos, M; Pedraza, V; Olea, N (1995). Xenoestrogens released from lacquer coatings in food cans. Environmental Health Perspective 103 :608-612

Burridge, E (2003) Bisphenol A. product profile . European Chemical News 17:14-20

Chang, HS; Choo, KH; Le, B;Choi, SJ (2009). The methods of identification,analysis and removal of removal of endocrine disrupting compounds (EDCs) in water. Journal of Hazardous Materials 172 (1):1-12

Dean, JR; Xion, C (2000) Extraction of organic pollutant from environmental matrices. Selection of extraction technique. Trends In Analytical Chemistry 19(9): 553-544
Holt, JG; Kragy, HR; Sneathe, RHA.; Willians, ST (1994) Bergey's manual of determinative bacteriology. $9^{\text {th }}$ edn. William and wilkens company Baltimore USA

HTN (2003). Focus on Africa, a critical need. Network for cost effective technologies in water supply and sanitation, St. gallien, Switzerland.

Ibe, SN; Okplenye, J I (2005) Bacteriological analysis of borehole water in Uli, Nigeria. African Journal Of Applied Zoology And Environmental Biology 7: 116-119

Jafari, A; Abasabad, R;Salehzadeh, A (2006). Endocrine disrupting contaminants in water resources and sewage in Hamadan City of Iran. Iranian Journal Of Environmental Health Science And Engineering 6(2): 89-96

Jagals, P; Bokaka, TC; Grabow, WOK.(1999).

Changing consumer water patterns and their effect on microbiological water quality as a result of an engineering intervention. Water South Africa 25: 297-300

Jin, X; Jiang, C; Huang, G.; Liu, J; Zhou, Q.(2004). Determination of 4-tertoctyphenol, 4nonylphenol and bisphenol $\mathrm{A}$ in surface water from Haihe River in Tianjin by gas chromatography-mass spectrometry with selected ion monitoring. Chemosphere 56(11): 1113-1119

Makinwa, TT; Uadia, PO (2015). A survey of the level of Bisphenol A (BPA) in effluents, soil leachates, food samples, drinking water, and consumer product in South-Western Nigeria World Environment 5(4): 135-139

Markey, CM; Michaelson, CL; Veson, EC; Sonnenschein, C; Soto, AM (2003). The mouseuterotropic assay: re-evaluation of its validity in assessing the estrogenicity of bisphenol A. Environmental Health Perspective 109: 55-60

Michael, k. (2000). A new mainstream text for the new specification. Advanced biology, oxford university press, New York pp 20-23

Osei, .Y. (2005). New school chemistry for senior secondary school. African first publishers ltd., Onitsha 
Raskari, N;Yunesian, M; Ahmadkhaniha, R (2011) Levels of bisphenol A and bisphenol $\mathrm{F}$ in canned foods in Iranian market. Iranian Journal of Environmental Health Science And Engineering 8(1):95-100

Rogbesan, AA; Eniola, KIT; Olayemi, AB (2002) Bacteriological examination of some boreholes within University of Ijebu-Ode. Nigerian Journal Of Pure And Applied Science 5(3): 117223

Szymanski,A; Rykowska,I; Wasiak, W (2006) Determination of bisphenol A in water and milk by micellar liquid chromatography. Acta Chromatography 17:161-172

Tambekar, DH; Hirulkar, NB; Bhokre, DD; Gulhane, SR; Bhanginwar, YS (2006). Water hygiene behaviours in hotels and restaurants and their effects on bacteriological quality. Biotechnology 5: 475-477

Tambekar, DH; Hirulkar, NB; Bhokre, DD; Gulhane, SR; Bhanginwar, YS (2006b). Studies of hygiene behavior on bacteriological quality deterioration of water in hotels and restaurants. Research Journal of Microbiology 5: 260-265

Vandenberg, LN; Maffini, MV; Sonnenschein, C; Rubin, BS; Soto, AM (2009) Bisphenol A and the great divide : a review of controversies in the field of endocrine disruption. Endocrine Review 30(1) :75-95

WHO. (1971 a). Guideline for drinking water quality. World health organization, Geneva

WHO. (1986 b). International standard for drinking water quality, world health organization. Geneva

WHO. (2011c). Guideline for drinking water quality. World health organization, Geneva

Wilson, NK; Chuang, JC; Morgan, MK; Lordo,RA; Sheldom, LS (2007) An observation al study of the potential exposure of preschool children to pentachlorophenol, bisphenol A and Onylphenol at home and daycare. Environmental Research 103 (1): 9-20 